\title{
Floor versus cage rearing: effects on production, egg quality and physical condition of laying hens housed in furnished cages
}

\author{
Cria em piso versus cria em bateria: efeitos na produção, qualidade de ovos e condição física de \\ poedeiras alojadas em gaiolas enriquecidas
}

\author{
Victor Fernando Büttow Roll' ${ }^{I}$ Ricardo Cepero Briz ${ }^{\text {II }}$ Gustavo Adolfo Maria Levrino ${ }^{\text {II }}$
}

\begin{abstract}
The influences of floor- and cage-rearing on egg production, egg quality and physical condition were investigated in laying hens housed in furnished cages. Two groups of 180 Isa Brown commercial layer pullets were reared in cages (CR) or floor pens (FR) and transferred to furnished cages, where their production, egg quality and physical condition was observed throughout the laying period (18-78wks of age). At 17 weeks of age, hens were placed in one of 36 furnished cages with 10 birds in each cage, each containing a nest box, perches, a dust bath, and abrasive strips. From 19 to 78 weeks of age, egg production data were collected daily. Commercial egg quality was assessed monthly. At, 19 and 78 weeks of age, claw length and feather cover were visually assessed using a four-point scale in a sample (10\%) of hens. Production variables were above breeders' standards and not significantly affected by rearing system. Dirty eggs and cracked eggs were more frequent in FR birds. Meat spots were significantly more frequent in FR hens at middle lay, but less frequently at the end of the laying period. Rearing system did not influence egg and yolk weight or unit Haugh and shell colour. Among FR hens, eggshell density, thickness and mass were significantly lower at the end of the laying period. Rearing system did not affect claw length, but the plumage of FR hens was negatively affected at the end of production cycle.
\end{abstract}

Key words: layer pullets, plumage, production, rearing system. RESUMO

Avaliou-se a influência dos sistemas de criação (em piso ou em baterias) sobre o desempenho produtivo, a qualidade de ovos e a condição física de poedeiras alojadas em gaiolas enriquecidas. Dois grupos de 180 frangas Isa brown foram criados em baterias (CR) ou em piso (FR) e transferidos para gaiolas enriquecidas, onde a produção, a qualidade de ovos e a condição física foram observadas durante um ciclo completo de postura (18-78 semanas de idade). Com 17 semanas de idade, as frangas foram alojadas em 36 gaiolas enriquecidas, 10 aves por gaiolas, cada uma contendo um ninho, poleiros, banho de areia e lixas de unhas. De 19 a 78 semanas de idade, a produção de ovos foi registrada diariamente. A qualidade comercial dos ovos foi medida mensalmente. Nas semanas 19 e 78 de idade, o comprimento das unhas e a condição da plumagem foram avaliadas utilizando-se uma escala de quatro pontos, numa amostra de $10 \%$ das aves. As variáveis produtivas estiveram acima dos padrões da linhagem e não foram afetadas significativamente pelo sistema de cria. Os ovos sujos ou trincados foram mais frequentes em poedeiras criadas em piso durante a metade do ciclo, mas menos frequentes ao final do ciclo de postura. $O$ sistema de cria não influenciou o peso dos ovos, a gema, a cor da casca ou as unidades Haugh. A densidade, espessura da casca e massa de ovos foram significativamente menores em galinhas criadas em piso, ao final do ciclo de postura. $O$ sistema de cria não afetou o comprimento das unhas, mas a conservação da plumagem das galinhas criadas em piso foi negativamente afetada ao final do ciclo de postura.

Palavras-chave: avicultura, desempenho, frangas de reposição, plumagem, sistema de criação.

\section{INTRODUCTION}

The council directive 1999/74EC, incorporated into law in Spain, states that by January 2003 all new cage system and by 2012 all existing cage must include nests, perches, abrasive strips and litter. Considering the suggestion of ANDERSON et al. (1989)

IDepartamento de Zootecnia, Faculdade de Agronomia Eliseu Maciel, Universidade Federal de Pelotas (UFPel), Campus Universitário s/n, CP 354, 96010-900, Pelotas, RS, Brasil. E-mail: roll98@ufpel.edu.br. Autor para correspondência.

IIDepartment of Animal Production \& Food Science, Faculty of Veterinary Medicine, University of Zaragoza, Miguel Servet 177, (50013) Zaragoza, Spain. 
that floor reared pullets are subjected to a drastic change in environment when housed in cages, the hypothesis considered was that adaptation problems can cause significant economic losses under commercial conditions and impair animal production.

A number of studies have shown that rearing systems affect the production period of hens housed in conventional cages (DEATON et al., 1985; ANDERSON \& ADAMS, 1994). For example, JIN \& CRAIG (1988) showed that rearing conditions can affect growth and egg production in laying hens, and ANDERSON \& ADAMS (1994) reported that hens reared in cages produce heavier eggs and are less fearful at the end of production cycle than floor-reared hens.

If differences exist between rearing system that can negatively or positively affect production period of hens housed in furnished cages, it must be found. The results herein could be helpful for deciding witch rearing system is more appropriate and brings less adverse consequence to the egg quality as well as the economy of a farm.

This study aimed to search for productivity, egg quality and physical condition differences between floored and caged reared birds to assess advantages and disadvantages of these two different rearing systems after transference to a furnished cage.

\section{MATERIAL AND METHODS}

Three hundred and sixty beak-trimmed pullets of a commercial strain (Isa Brown) were purchased from a local breeder. On the farm of origin, half of the birds were reared in standard rearing cages and the other half were reared in floor pens with litter. The management of both treatments was otherwise similar and all birds were managed according to standard commercial practices.

Chicks were fed standard pullet feed in three phases: 21\% CP, $2823 \mathrm{kcal} \mathrm{ME} \mathrm{kg}^{-1}$ starter diet from 0-6 weeks; 18\% CP, $2864 \mathrm{kcal} \mathrm{ME} \mathrm{kg}^{-1}$ grower diet from 712 weeks; and 16\% CP, 2724 kcal ME kg-1 developer diet from 13-17 weeks.

At 17 weeks of age, the birds were transferred to the Poultry Experimental Unit of the University of Saragossa and randomly allotted to one of 36 furnished cages, each with 10 birds per cage. There were two main treatments, arranged in two blocks of 18 cages. The furnished cages have a nest and litter at the rear (Figure 1). The cages were $120 \mathrm{~cm}$ wide, $63 \mathrm{~cm}$ deep, and $40 \mathrm{~cm}$ high at the front and $45 \mathrm{~cm}$ high at the back, with a floor slope of $12^{\circ}$. The average area per bird was $600 \mathrm{~cm}^{2}$ in the main part of the cage and $150 \mathrm{~cm}^{2}$ in the nest area (total floor space per bird was750 $\mathrm{cm}^{2}$ ). Feeder area was $12 \mathrm{~cm}$ per bird and space in the dust bath was $120 \mathrm{~cm}^{2}$ per bird.

From 18 to 78 weeks of age, hens had ad libitum access to water and normal layer crumbled rations with $2892 \mathrm{kcal} \mathrm{ME}^{\mathrm{kg}}{ }^{-1}$ and $17 \%$ crude protein. The light-dark regime was 16:8. Air temperature was maintained between 20 and $24^{\circ} \mathrm{C}$. Hens had access to a dust bath for $2 \mathrm{~h}$ per day (13-15h, after egg collection). To prevent hens from staying in the litter box area, expulsion system was used. That period was chosen to prevent hens from laying in the dust bath, and to adjust the hens to the working hours of farm employees. Faeces were removed with conveyor belts and dust baths were filled with sawdust (previously passed through a sieve), automatically, using conveyor belts on alternate days. From 19 to 78 weeks of age, production data (including the number of damaged or dirty eggs) were collected daily.

The commercial quality of 780 eggs (390 eggs per treatment) was analyzed in 13 samples. For statistical analyses, the data were pooled into one of three periods (beginning 20-29 weeks, middle 40-59 weeks and end of lay 60-78 weeks). To quantify the number of cracked and dirty eggs, an egg-candler was used. The eggs with approximately $10 \%$ of the shell surface area covered with sawdust, blood spots or faeces were considered dirties. Egg Quality Meter $\left(\mathrm{EQM}^{\circledR}\right.$, Version 3.1 Technical Services \& Supplies, UK) was used to measure egg quality. The following variables were measured: egg weight, shell colour, albumen quality (Haugh Units), yolk weight, shell density, shell thickness, and shell weight. Yolk colour was measured with a Minolta CM 2002 spectrophotometer with standard illuminant $\mathrm{C}$ and $2^{\circ}$ standard observer using the CIE L* $\mathrm{a}^{*} \mathrm{~b}^{*}$ system (lightness. $\mathrm{L}^{*}$ : redness. $\mathrm{a}^{*}$ : yellowness. $\mathrm{b}^{*}$ ). Shell thickness was recorded as the average of the three equidistant points on the eggs' equator, and measured using a digital micrometer (Mitutoyo Model 547-301; accuracy $=0.01 \mathrm{~mm}$ ). Eggshell thickness was measured after the egg was broken and dried at $70^{\circ} \mathrm{C}$ for $24 \mathrm{~h}$. After broken the eggs, blood and meat spots were directly estimated through visual examination of the eggs on a surface equipped with a mirror table. Eggshell colour was measured by the reflected light (\%) using the EQM reflectometer.

To score feather condition in six parts of the body (neck, breast, back, wings, tail, and cloaca area), a four point scoring system of TAUSON et al. (1984) was used. Two weeks after transferring the pullets to the experimental unit (19 weeks of age) no damage to the plumage was recorded (total 24 points: very good 


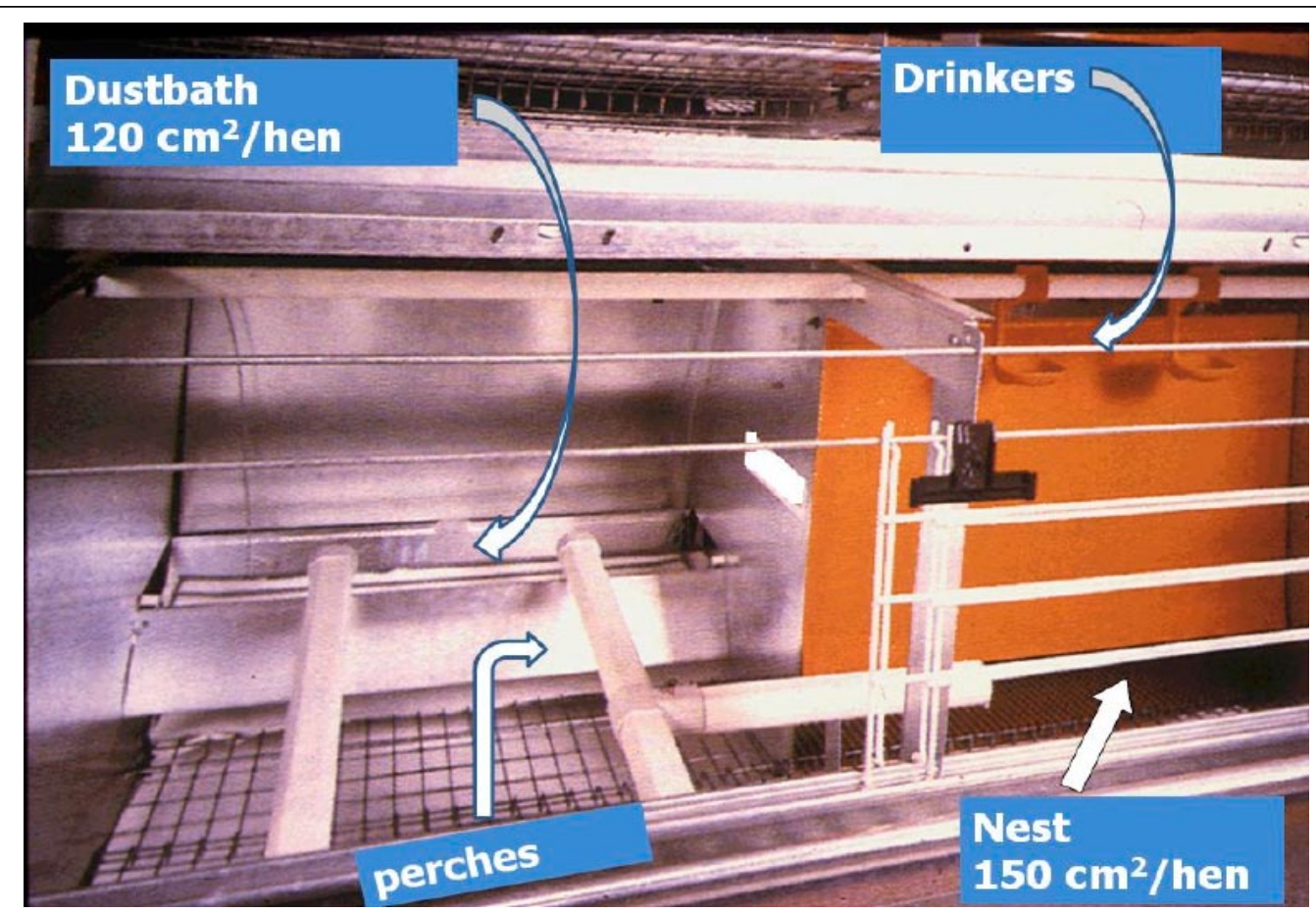

Figure 1 - Schematic representation of the furnished cages used in the experiment.

plumage and completely covered by feathers). At 78 weeks of age, a sample (10\%) of hens was assessed visually and compared to standard photographs. Overall average score and a score for each part of the body (4: very good plumage and completely covered by feathers - 1 : very damaged plumage and not covered by feathers) was determined. Claw length of the central toe on the right foot along its curvature was measured with a metric tape.

Statistical analysis: untransformed data of egg production and egg quality, except dirty or cracked eggs, or blood and meat spots were analysed using the least mean squares procedure. The Wilcoxon rank sum procedure (Mann-Whitney U-test) was used for testing the differences in the frequency of meat and blood spots in eggs. Before analysis, the proportions of cracked and dirty eggs were arcsine transformed. Floor- and cage-rearing were treated as the experimental unit and, for all traits. Individual cages were used as replicates. The level for statistical significance was set at $\mathrm{P}<0.05$ and statistical tests were performed using SPSS 11.0 for Windows.

\section{RESULTS AND DISCUSSION}

Production

Rearing systems groups did not differ for any production variables. At 78 weeks of age, Floor- reared (83.2\%) and Cage-reared (82.6\%) showed no significant difference in egg production (\% hen housed). Average egg weight (g), egg mass (g hen day $^{-1}$ ), egg mass ( $\mathrm{kg}$ hen housed ${ }^{-1}$ ) were 66.6, 55.4, 22.9 for FR hens and 66.7, 55.1, 22.8 for CR hens, respectively. Mortality was very low in both treatments (3.4\% in CR hens; 3.8\% in FR hens).

Egg production, egg quality and the behavioural traits of laying hens are considered good indicators of how well they adapt to furnished cages (TAUSON, 1992). Production traits, which were above breeder's standards, were not affected by rearing system, as found in another study (JIN \& CRAIG, 1988). Egg production and hen mortality were similar to those observed by TAUSON (1998), who reported a mean egg mass per hen of $22.3 \mathrm{~kg}$ and $3.2 \%$ mortality when hens were housed in enriched cages, and $21.8 \mathrm{~kg}$ and $5.8 \%$ in hens housed in conventional cages. CEPERO et al. (2000) reported similar results. Egg weight did not vary significantly between the rearing systems, which is in contrast to the finding of ANDERSON \& ADAMS (1994), who reported that hens reared in cages produced heavier eggs than those reared in floor pens after their transference to conventional cages. In this study, rearing system did not influence hen mortality, as reported by ANDERSON \& ADAMS (1994) for hens housed in conventional cages.

Ciência Rural, v.39, n.5, ago, 2009. 
Egg quality

The possible effects of rearing system on egg quality were tested in 3 phases during the laying period (Table 1). When compared with CR hens, the proportion of dirty eggs was significantly $(\mathrm{P}<0.05)$ higher in FR hens at the middle and final phase of the production cycle. Significant higher proportions of cracked eggs were observed in FR hens at the beginning and middle of laying period $(\mathrm{P}<0.05)$. Yolk colour, which was measured using the $L^{*} a * b *$ system, only differed between treatments for $b^{*}$ (yellowness) at the end of the laying period. Meat spots were more frequent $(\mathrm{P}<0.05)$ in FR hens at middle lay, but the opposite was observed at end of lay. With increasing age of the hen, the frequency of blood spots increased and meat spots remained stable throughout the production period, except in FR hens during the middle lay period. Rearing system did not affect shell colour, egg and yolk weight or albumen quality, as measured by Haugh Units. Shell density, shell thickness and shell weight were significantly $(\mathrm{P}<0.05)$ lower in FR hens at the end of lay, only.

Egg quality traits, such as cracks and dirtiness, might be negatively affected by cage design (ABRAHAMSSON \& TAUSON, 1998). The negative effects of cage design might be greater in floor-reared hens than in cage-reared hens because of the higher frequency of nesting and perching behaviour in the former (ELSTON et al., 2000).
The differences observed in behaviour of hens in the two treatment groups might affect egg quality (SMITH et a1., 1993). FR hens used the dust bath more often than did CR hens (data not showed). The higher activity of FR hens might have had a negative effect on eggshell cleanliness because the eggs could be coated with sawdust from the egg collection belt (located just under the belt used for the distribution of dust bath material), particularly if there were broken eggs on the belt. The external condition of eggs is important because bad quality can reduce its price (ABRAHAMSSON \& TAUSON 1995). The proportion of dirty eggs was lower than reported in other studies (ABRAHAMSSON et al., 1996; WALL \& TAUSON, 2002; MALLET et al., 2003).

Some designs of furnished cages have produced relatively more broken eggs than observed in this study (APPLEBY et al. 1998; VAN NIEKERK \& REUVENKAMP, 1999; WALL \& TAUSON, 2002; HIDALGO \& ROSSI, 2003; ABRAHAMSSON et al., 1996).

SHORT et al. (2001) suggested that competition among hens for access to a dust bath might produce increased stress in hens, which in turn reduces eggshell density. No evidence was found to support that hypothesis, at least at the beginning and middle phases of the laying period, but might explain the higher frequency of broken eggs at the end of laying in FR hens.

Table 1 - Commercial egg quality parameters (mean \pm SE) of floor-reared and cage-reared ISA Brown laying hens housed in furnished cages.

\begin{tabular}{|c|c|c|c|c|c|c|}
\hline & \multicolumn{2}{|c|}{-_-_----20-39weeks--_----- } & \multicolumn{2}{|c|}{---_----40-59weeks----_---- } & \multicolumn{2}{|c|}{ 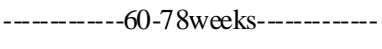 } \\
\hline & Floor & Cage & Floor & Cage & Floor & Cage \\
\hline Dirty eggs ${ }^{1}, \%$ & 2.1 & 3.0 & $3.7^{\mathrm{a}}$ & $2.6^{\mathrm{b}}$ & $8.1^{\mathrm{a}}$ & $4.7^{b}$ \\
\hline Cracked eggs ${ }^{1} \%$ & $2.2^{\mathrm{a}}$ & $1.6^{\mathrm{b}}$ & $1.6^{\mathrm{a}}$ & $1.2^{\mathrm{b}}$ & 2.5 & 2.1 \\
\hline Egg weight. g & $67.0 \pm 0.7$ & $65.7 \pm 0.6$ & $66.7 \pm 0.5$ & $67.5 \pm 0.6$ & $69.5 \pm 0.4$ & $70.1 \pm 0.4$ \\
\hline Yolk. g & $15.9 \pm 0.1$ & $15.4 \pm 0.1$ & $16.6 \pm 0.1$ & $16.5 \pm 0.1$ & $17.4 \pm 0.1$ & $17.6 \pm 0.1$ \\
\hline Yolk colour L* & $60.7 \pm 0.4$ & $61.1 \pm 0.3$ & $59.2 \pm 0.2$ & $59.4 \pm 0.3$ & $59.2 \pm 0.2$ & $58.9 \pm 0.2$ \\
\hline Yolk. colour a* & $8.8 \pm 0.2$ & $8.9 \pm 0.2$ & $9.9 \pm 0.1$ & $9.8 \pm 0.2$ & $9.8 \pm 0.1$ & $9.7 \pm 0.1$ \\
\hline Yolk colour b* & $43.7 \pm 0.4$ & $43.2 \pm 0.4$ & $43.6 \pm 0.4$ & $44.3 \pm 0.3$ & $44.6 \pm 0.2 \mathrm{a}$ & $43.9 \pm 0.2 b$ \\
\hline Haugh units & $91.0 \pm 0.7$ & $90.6 \pm 1.0$ & $91.1 \pm 0.9$ & $88.8 \pm 0.8$ & $83.1 \pm 0.7$ & $82.1 \pm 0.9$ \\
\hline Blood spots ${ }^{2}, \%$ & 13.3 & 10.0 & 20.0 & 23.3 & 29.5 & 29.5 \\
\hline Meat spots ${ }^{2}, \%$ & 18.3 & 21.6 & $35.0 \mathrm{a}$ & $20.0 \mathrm{~b}$ & $16.1 \mathrm{a}$ & $24.1 \mathrm{~b}$ \\
\hline S. colour (\%) & $33.6 \pm 0.6$ & $33.4 \pm 0.6$ & $34.4 \pm 0.7$ & $35.3 \pm 0.8$ & $37.2 \pm 0.4$ & $37.0 \pm 0.4$ \\
\hline S. density $\mathrm{g} \mathrm{cm}^{-2}$ & $78.0 \pm 0.9$ & $80.2 \pm 1.0$ & $79.4 \pm 0.8$ & $80.3 \pm 0.9$ & $76.8 \pm 0.6^{\mathrm{a}}$ & $78.9 \pm 0.6^{b}$ \\
\hline S.thickness $(\mu)$ & $409.8 \pm 3.5$ & $417.3 \pm 3.9$ & $412.7 \pm 3.2$ & $416.9 \pm 4.0$ & $401.1 \pm 2.6^{\mathrm{a}}$ & $408.0 \pm 2.6^{b}$ \\
\hline S. weight. g & $6.48 \pm 0.07$ & $6.49 \pm 0.08$ & $6.57 \pm 0.06$ & $6.6 \pm 0.08$ & $6.4 \pm 0.05^{\mathrm{a}}$ & $6.6 \pm 0.05^{b}$ \\
\hline
\end{tabular}

${ }^{1}$ presented as mean values instead of least-squares means because the data were arcsin transformed.

${ }^{2}$ presented as percentage values, rather than the descriptive statistics of Mann-Whitney tests.

Means within columns with no common superscripts differ significantly (at least $\mathrm{P}<0.05$ ).

"S" = Shell.

Ciência Rural, v.39, n.5, ago, 2009. 
Eggshell colour might be a useful indicator of a hen's welfare. In hens experiencing a certain degree of stress, the eggs remain in the oviduct for a longer period of time, leading to deposition of amorphous calcium carbonate and resulting in whiter eggs (WALKER \& HUGHES 1998). The lack of a difference in eggshell colour suggests that the welfare status of hens was similar in both treatments. The high frequencies of blood and meat spots observed in both treatment groups are difficult to explain, but they might be the result of the grading criteria used, which were stricter than those used in a commercial classification system, where the frequency of blood and meat spots should be lower. ABRAHAMSSON \& TAUSON (1998) report blood and meat spots on $2-5 \%$ and $1.2-7.0 \%$ of eggs. The proportion of spots increased with the age of hens in both treatments.

\section{Physical condition}

At the end of the laying period, feather condition and cover were significantly better in CR hens than in FR hens $(\mathrm{P}<0.05)$. The cumulative declining in the overall score was $-26 \%$ in CR hens and - $37 \%$ in FR hens (17.6 vs. 15.0 points). The region of the body that exhibited the greatest feather degradation was the breast (-65\% and -72\% in CR and FR hens, 1.4 vs. 1.1 points, respectively) and the lowest degradation was observed on the back (-15\% and $-25 \%$ in CR and FR hens, 3.4 vs. 3.0 points respectively). Feather condition in the cloacal region declined significantly more in FR hens $(-37 \%)$ than in CR hens (-17\%). In the neck region, differences were observed in favour of CR hens. Hens from the two rearing treatments did not differ significantly in the condition of wing feathers. Mean claw length was $1.6 \mathrm{~cm}$ at 19 weeks of age and 2.1 at 78 weeks of age and did not differ significantly between the two rearing systems.

Claw length and feather scores provide information about the welfare status of hens (TAUSON, 1984). It is plausible that FR hens maintain scratching behaviour more intensively than do CR hens, mainly by scratching their feet on the abrasive strips on the egg guard while feeding or in the dust bath while dust bathing. This might reduce feather loss, particularly on the back of the hens due to excessive claw length.

The percentage of hens scored for plumage conditions by a trained observer is a reasonable indicator of feather pecking behaviour (GUNNARSSON et al., 2000). According to the data obtained in the experiment, plumage condition was acceptable at the end of the laying period. The average feather score was higher ( 21 vs. 18.5 points on a scale of 24) than reported by ABRAHAMSSON et al. (1996) for hens of an age similar to those herein observed. Similar to the observations of JIN \& CRAIG (1988), at the end of laying period, plumage condition was better in CR hens than in FR hens. The poor plumage condition of the breast of FR hens was due to the higher use of and abrasion from perches and greater dust-bath activity. Other regions of the hen's body had poor plumage, but they were not exposed to abrasion. Thus, there might have been feather pecking at the end of lay in FR hens, but it was not very pronounced. Average claw length was shorter than reported by BARNET et al. (1997), but longer than those of pen-housed hens in the same study. No effect of rearing system on claw length was found. Although more data are required, it is plausible that scratching behaviour in Isa Brown laying hens is not affected by rearing system.

\section{CONCLUSION}

Production variables were similar in floorand cage-reared Isa Brown laying hens; however, some measures of egg quality, e.g., dirty eggs and shell quality, were slightly worse in floor-reared hens. There is one possible explanations for this; the higher activity on the dust bath (eggs could be coated with sawdust) of floor-reared hens might have had a negative effect on eggshell cleanliness.

\section{ACKNOWLEDGEMENTS}

This research was supported by the Ministry of Science and Technology of Spain (Projects AGF97-0932 and PETRI PTR 1995 0449-OP) and co-supported by Zucami Poultry Equipment Company, The Spanish Association of Egg Producers (INPROVO) and the Ministry of Agriculture \& Fisheries of Spain. The authors would like to thank Conselho Nacional de Desenvolvimento Científico e Tecnológico (CNPq) from Brazil for the financial support of the Ph. D. student Victor Fernando Büttow Roll

\section{REFERENCES}

ABRAHAMSSON, P.; TAUSON, R. Aviary systems and conventional cages for laying hens. Effects on production, egg quality, health and birds location in three hybrids. Acta Agriculturae Scandinavica Section A, Animal Science, Copenhagen, v.45, n.3, p.191-203, 1995.

ABRAHAMSSON, P. et al. Behaviour, health and integument of four hybrids of laying hens in modified and conventional cages. British Poultry Science, London, v.37, n.3, p.521540, 1996 .

ABRAHAMSSON, P.; TAUSON, R. Performance and egg quality of laying hens in aviary system. Journal of Applied Poultry Research, Athens, v.7, n.3, p.225-232, 1998.

ANDERSON, K.E. et al. Behavioral adaptation of floor-reared white Leghorn pullets to different cage densities and cage shapes 
during de initial settling-in period. Poultry Science, Savoy, v.68. n.1, p.70-78, 1989.

ANDERSON, K.E.; ADAMS, A.W. Effect of floor versus cage rearing and feeder space on growth long bone development, and duration of tonic immobility in single comb White Leghorn pullets. Poultry Science, Savoy, v.73, n.7, p.958-964, 1994.

APPLEBY, M.C. et al. Factors affecting the use of perches in cages by laying hens. British Poultry Science, London, v.39, n. 2, p.186-190, 1998.

BARNET, J.L. et al. Effects of modifying layer cages with perches on stress physiology, plumage, pecking and bone strength of hens. Australian Journal of Experimental Agriculture, Melbourne v.37, n.5, p.523-529, 1997.

CEPERO, R. et al. Productividad en jaulas enriquecidas: resultados preliminares. In: SYMPOSIUM WORLD POULTRY SCIENCE ASSOCIATION 37., 2000, Spain. Proceedings... Barcelona: World's Poultry Science Association, 2000. p.176-184.

DEATON, J.W. et al. Noted difference in the digestive system in cage and floor-reared commercial egg-type pullets. Poultry Science, Savoy, v.64, n.5, p.1035-1037, 1985.

ELSTON, J.J. et al. Laying hen behaviour. Effect of cage type and startle stimuli. Poultry Science. Savoy, v.79, n.4, p.471-476, 2000.

GUNNARSON, S. et al. Rearing without early access to perches impairs the spatial skills of laying hens. Applied Animal Behaviour Science, Amsterdam, v.67, n.3, p.217-228, 2000. DOI: $10.1016 /$ S0168-1591(99)00125-2

HIDALGO, A.; ROSSI, M. Influence of alternative housing systems on table egg quality. In: SYMPOSIUM EGG \& EGG PRODUCTS, 10., 2003, France. Proceedings... Yves Nys (INRA), St. Brieuc: World's Poultry Science Association, 2003. p.231-237.

JIN, L.; CRAIG J.V. Some effects of cage and floor rearing on commercial White Leghorn pullets during growth and the first year on egg production. Poultry Science, Savoy, v.67, n.10, p.1400-1406, 1988.

MALLET, S. et al. Comparison of egg shell quality and hygiene in two housing systems/ standart and furnished cages. In: SYMPOSIUM ON THE QUALITY OF EGGS AND EGGS PRODUCTS, 10., 2003, France. Proceedings... Yves Nys (INRA), St. Brieuc: World's Poultry Science Association, 2003. p.238-242.

SHORT, F.J. et al. Egg shell density in furnished cages: Effect of dustbath and perch provision. British Poultry Science, London, v.41, suppl.1, p.s77-s78, 2001.

SMITH, S.F. et al. Nesting and dust bathing by hens in cages: Matching and mis-matching between behaviour and environment. British Poultry Science, London, v.34, n.l, p.21-33, 1993.

TAUSON, R. et al. Evaluation of procedures for scoring the integument of laving hens - Independent scoring of plumage condition. Acta Agriculturae Scandinavica Section A, Animal Science. Copenhagen, v.34, n.3, p.400-408, 1984.

TAUSON, R. Studies on alternative keeping systems for laying hens in Sweden. Sweden: Dept. of Animal Nutrition and Management, Swedish University of Agricultural Sciences, 1992. 33p. ( Rapport 209).

TAUSON, R. Health and production in improved cage designs. Poultry Science, Savoy, v.77, n.12, p.1820-1827, 1998.

VAN NIEKERK, T.C.G.M.; REUVEKAMP, B.F.J. Enriched cages for laying hens. World Poultry, Doetinchem, v.15, n.12, p.34-37, 1999.

WALL, H.; TAUSON, R. Egg quality in furnished cages for laying hens - Effects of crack reduction measures and hybrid. Poultry Science, Savoy, v.81, n.3, p.340-348, 2002.

WALKER, A.W.; HUGHES, B.O. Egg shell colour is affected by laying cage design. British Poultry Science, London, v.39, n.5, p.696-699, 1998. 